\title{
REFERENCE:
}

Aporosa, S.A. (2019). Kava and ethno-cultural identity in Oceania. In S. Ratuva (Ed.),

The Palgrave handbook of ethnicity. Chapter 134-1. (pp. 1-15 [online-first release]).

Singapore: Springer Nature. doi:0.1007/978-981-13-0242-8_134-1

\section{Kava and Ethno-cultural Identity in Oceania}

\section{S. Apo Aporosa}

\section{Contents}

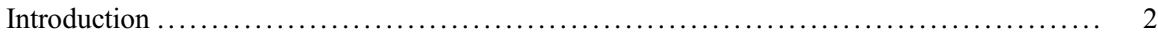

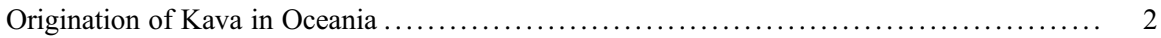

Kava Preparation, Effect, and Oceanic Identity ................................. 3

Yaqona (Kava) and National Ethno-cultural Identity in Fiji ........................... 4

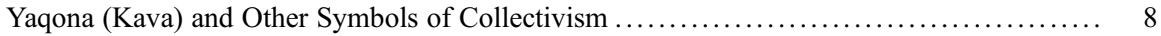

Fijian-ness, Yaqona, and Government ........................................ 9

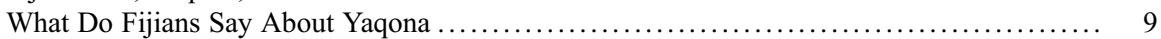

Yaqona and Ethno-cultural Identity in Diaspora .................................. 9

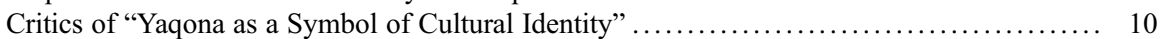

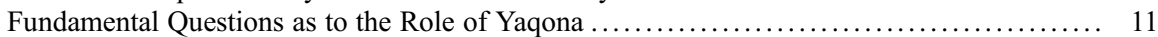

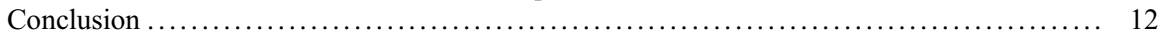

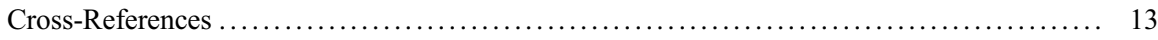

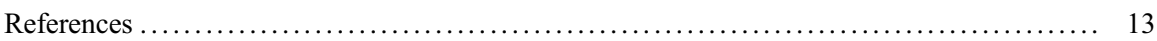

\begin{abstract}
Garibaldi and Turner (Ecol Soc 9:1, 5, 2004) explain the role that particular plants play in facilitating the shared ancestry, practices, and social experience of an ethnicity. This can include spiritual connections, cultural expression and practice, ceremony, exchange, linguistic reflection, socialization, and medicinal and/or dietary systems. They term these plants "cultural keystone species" and icons of identity, plants that if removed would cause some disruptions to the cultural practices and identity of an ethnic group. Undoubtedly, kava (Piper methysticum) is the cultural keystone species for many Oceanic and Pacific peoples, a "differentiating element of common culture" (Zagefka, Ethnicity, concepts of. In: Smith AD, Hou X, Stone J, Dennis R, Rizova P (eds) The Wiley Blackwell
\end{abstract}

\footnotetext{
S. A. Aporosa ( $\bowtie)$

Te Huataki Waiora: Faculty of Health, Sport and Human Performance, University of Waikato, Hamilton, Waikato, New Zealand

e-mail: apo.aporosa@waikato.ac.nz
} 
encyclopedia of race, ethnicity, and nationalism. West Wiley, Sussex, pp 761-763, 2016) informing their ethno-cultural identity. That influence is also extending to new non-Pacific Island user groups who have embraced elements of kava ethno-cultural identity in what has been termed diasporic identity formation in reverse. This chapter will discuss kava with specific reference to ethnic positionality in Fiji while recognizing the tensions from inside and outside the region that support and threaten the continuance of the kava drinking tradition.

\section{Keywords}

Identity $\cdot$ Kava $\cdot$ Yaqona $\cdot$ Fiji $\cdot$ Oceanic Pacific cultural identifiers $\cdot$ Evangelical

\section{Introduction}

Garibaldi and Turner $(2004$, p. 1, 5) explain the role that particular plants play in facilitating the shared ancestry, practices, and social experience of an ethnicity. This can include spiritual connections, cultural expression and practice, ceremony, exchange, linguistic reflection, socialization, and medicinal and/or dietary systems. They term these plants "cultural keystone species" and icons of identity, plants that if removed would cause some disruptions to the cultural practices and identity of an ethnic group. Undoubtedly, kava (Piper methysticum) is the cultural keystone species for many Oceanic and Pacific peoples, a "differentiating element of common culture" (Zagefka 2016, p. 761) informing their ethno-cultural identity. That influence is also extending to new non-Pacific Island user groups who have embraced elements of kava ethno-cultural identity in what has been termed diasporic identity formation in reverse. This chapter will discuss kava with specific reference to ethnic positionality in Fiji while recognizing the tensions from inside and outside the region that support and threaten the continuance of the kava drinking tradition.

\section{Origination of Kava in Oceania}

The kava plant, of the genus Piper methysticum, is found across much of tropical Oceania. Growing several meters tall and with six to eight thick noded stems and heart-shaped leaves extending from a central basal stump, kava's importance is reflected in the traditional narratives of Pacific Oceanic people groups from Papua New Guinea in the west to Hawaii in the east (Lebot et al. 1992, p. 121). Lindstrom (2004) explains that although there is some variation in these narratives, they contain a common theme of regeneration and fertility empowered by local ancestral spirits and gods, with these recited "to legitimate contemporary behavioural patterns and understandings" (p. 12).

Botanical, linguistic, and genetic evidence suggests that the kava plant was originally found by the Austronesian Lapita culture in northern Vanuatu around 3000 years ago (Lebot et al. 1992). That "finding" has led to other narratives. For 
instance, this tropical shrub is asexual - without seeds and requiring manual propagation - which has led to its status becoming a "plant of the gods," believed to have been nurtured by the gods until the arrival of those first Austronesians in Vanuatu. This link with the gods is argued to imbue kava with mana (or spiritual power) (Aporosa 2014). Mana is also believed to give kava its medicinal efficacy, which includes mild anesthetic, analgesic, and anti-inflammatory properties and antifungal, amebicidal, anticonvulsant, antimicrobial, anticancer, and anxiolytic activity (Lebot and Cabalion 1988; Lim 2016).

Vanuatuan anthropologist Kirk Huffman (2012), reflecting on the spread of kava from Vanuatu, has observed: "Well cut and wrapped fresh kava branches can be planted after sea voyages of up to two weeks... Thus, we can attribute the entire distribution of drinkable kava across the Pacific to the earlier maritime explorers of the region, long before the late arrival of European explorers" (p. 25). In their Eastern Polynesian anthropologically focused text, Kirch and Green (2001) agree with Huffman's thesis: "we can be certain it $[\mathrm{kava}]$ was introduced from the West. Most probably, this occurred with or just after the initial Lapita settlement of FijiTonga-Samoa region" (p. 256). It is speculated that early trading by Lapita peoples also introduced kava to areas west of Vanuatu, including selected regions of Papua New Guinea (Lebot et al. 1992).

Although trade is cited as a significant reason for kava's distribution across the Pacific, Lebot et al. (1992) also cite the role of "traditional exchange ... [which] links people with their gods and ancestral spirits" (p. 120). That union between kava and traditional spiritualism and mana suggests that early traders, who frequently negotiated dangerous stretches of open water, would have carried kava with them for protection while also having an item of spiritual significance on hand to offer to, and acknowledge, those they met en route and to forge trading alliances (Lebot et al. 1992, p. 142). That connection with gods and ancestral spirits is believed to have been enhanced through the consumption of kava beverage (Lebot et al. 1992).

\section{Kava Preparation, Effect, and Oceanic Identity}

Kava is made by steeping the crushed green or dried roots of the kava plant in water to make a slightly peppery earthy flavored drink (Fig. 1). In Vanuatu and the kava using regions to the west, kava is mixed with less water and therefore is stronger in concentration than typically prepared in Fiji and the islands to the east (Aporosa 2014). Active properties within kava, called kavalactones, dull receptors in the central nervous system leading to a slight numbing and slowing in the response time in the muscles, limbs, and brain creating a relaxed, peaceful, lethargic feeling (Aporosa 2011, 2017). This does not lead to marked euphoria or hallucination, as kava "intoxication" includes a clear mindedness, which facilitates quality conversation and decision-making (Aporosa and Tomlinson 2014).

Lebot et al. (1992) report that kava "plays a unique role in the social life of many Pacific societies... [as part of] asserting their cultural identity" (p. 198). Pacific and Social Science researchers have reported widely on the link between identity and 
Fig. 1 Contemporary kava mixing using cloth 'mixing bag'. (Source: Payson 2008, p. 122)

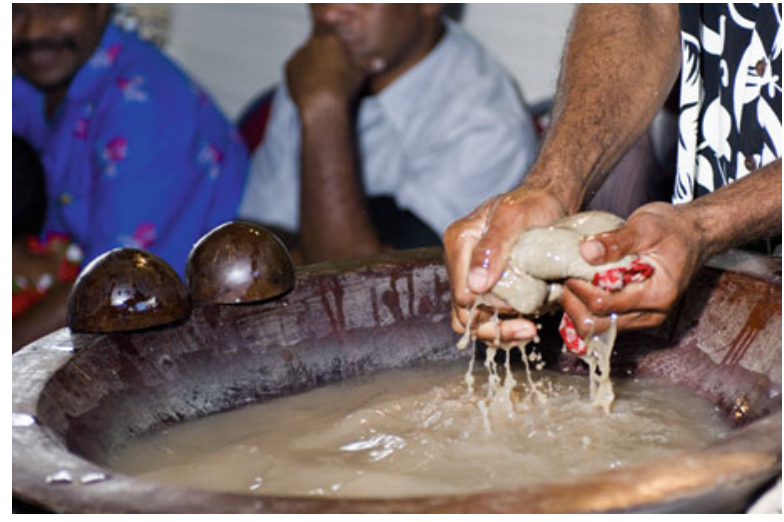

kava use across Oceania (Aporosa 2014, pp. 35-44). This includes selected areas of Papua New Guinea, notably in the Middle Fly District, where the Gogodala people continue to use kava today (Crawford 1981) together with the islanders of Pohnpei in the Federated States of Micronesia. Balick and Lee (2009) report that both the plant and the drink made from it play a critical role in "defining Pohnpeian cultural identity" (p. 165).

Kava in Vanuatu is described as important to outworking kastom, being a "symbol of national identity" (Young 1995, p. 61). Finau et al. (2002) also highlight kava use in Tonga through which "Tongan's have maintained their cultural identity" (p. 59). Fehoko (2014) adds that kava consumption venues act as sites of cultural continuance in which values, language, traditions, and beliefs are "reinforced. . . thus reaffirming their Tongan identity" (p. 91; also see Matthias 2014). In Samoa, kava is considered "an important cultural symbol and a traditional sign of hospitality" (Minahan 2012, p. 279). Tengan (2008) tells an alternate story, an account of the impact of missionization, colonization, and cultural loss in Hawaii. This has now being addressed through a reengagement with kava as part of reestablishing traditional knowledge and enhancing identity. Anthropologist Dr. Nancy Pollock (1995) summarizes the importance of kava to ethno-cultural identity across Oceania: "In Tonga, Samoa, Futuna, Fiji and Pohnpei kava usage persists as an 'external symbol' of both current and past ideologies" (p. 2). Pollock's reference to Fiji provides the focal point for this chapter, the cultural keystone role that yaqona (kava) plays in Fijian ethnicity and identity both in Fiji and the Fijian diasporic communities.

\section{Yaqona (Kava) and National Ethno-cultural Identity in Fiji}

Yaqona (more commonly known as kava), when coupled with its associated rituals and practices, is commonly recognized as a potent symbol of Fijian ethno-cultural identity (Aporosa 2008). Fijians colloquially refer to kava as grog (Geraghty 1996), although when spoken of in more formal discussion, both yaqona and particularly wainivanua (or "water of the vanua") are used. To explain this connection, and 
Fig. 2 Postcard: Fijian serving yaqona. (Unknown producer)

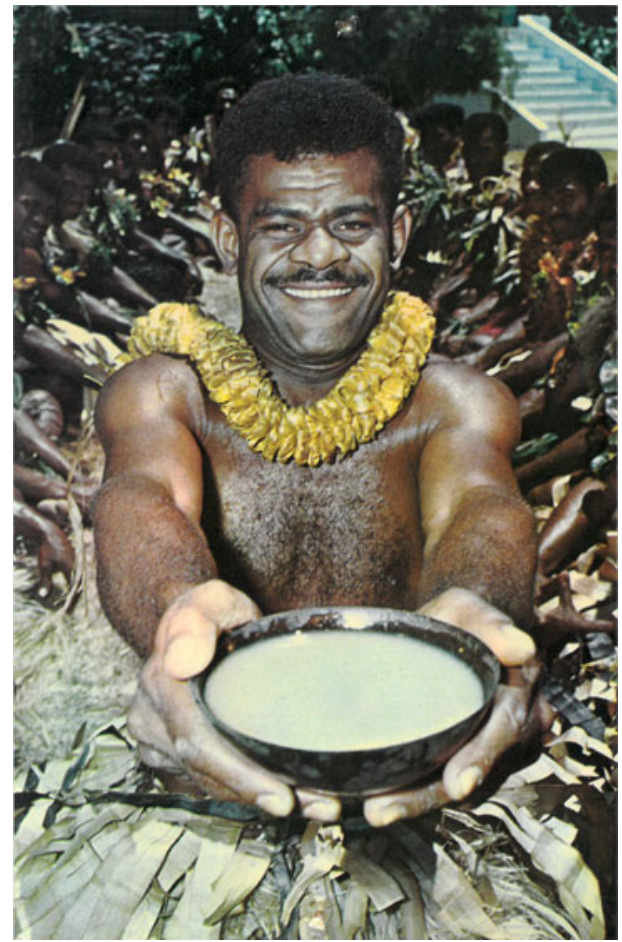

Fig. 3 Fijian one-cent piece. (Source: Government of Fiji 2006)

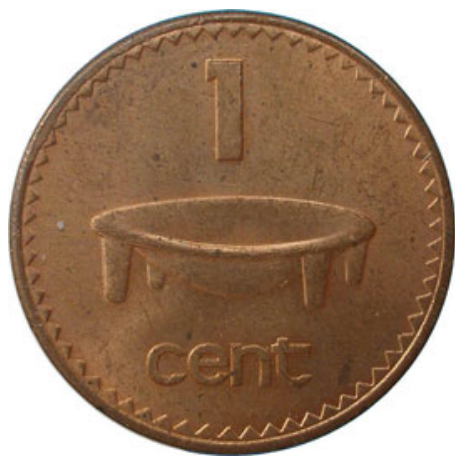

particularly the linguistic significance of the word wainivanua in more detail, Ravuvu (1983) states:

Vanua literally means land, but also refers to the social and cultural aspects of the physical environment identified with a social group. On the social plane it includes people and how they are socially structured and relate to one another. On the cultural plane it embodies the values, beliefs and the common ways of doing things. (p. 76) 
Fig. 4 Polo shirt logo: Ratu Sukuna Bowl. (Source: Republic of Fiji Military Forces 2009)

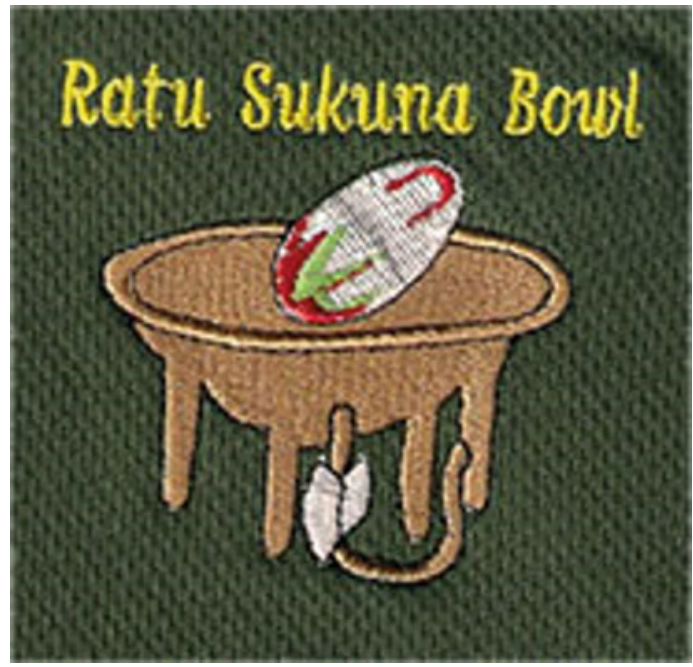

Therefore, when combining understandings of vanua with the word wainivanua, this "infers an ingestible representation of the land, people and culture ... which is deeply rooted in their sense of identity and customary practices" (Aporosa 2014, p. 68). Once prepared, yaqona (the descriptor that will predominantly be used in this chapter when referring to kava in Fiji) becomes a sacred and living entity that both embodies mana and has the ability to enhance a person's mana (Turner 1986; Tomlinson 2004).

In most villages across Fiji, when the working day ends, men, and occasionally women, sit cross-legged at the tanoa (yaqona bowl) to discuss the day and plans for the next, along with the latest news or gossip (Aporosa 2008). Yaqona's expression of Fijian-ness, and as an embedded symbol of ethno-cultural identity, has led to icons such as the tanoa and the preparation and/or serving of yaqona frequently being drawn on as a symbol of Fiji (Fig. 2). For instance, the tanoa is depicted on the Fijian one-cent piece (Fig. 3) and also comprises the logo and trophy for the annual Ratu Sukuna Bowl and interservices (police vs. army) rugby competition (Fig. 4) (Dean and Ritova 1988).

According to Ratuva (2007, pp. 92-99) and Vakabua (2007, p. 103), the drinking of yaqona demonstrates, externalizes, and personifies "Fijian-ness" and the Fijian way. Such notions are demonstrated through the union of the tanoa with Ratu Sir Lalabalavu Sukuna (1888-1958), a Fijian chief, decorated soldier (French Foreign Legion), statesman, and Oxford University scholar who many argue personifies the "ideal Fijian" (Scarr 1980; Lal 1985). By uniting one of Fiji's most revered leaders with the tanoa - and vicariously wainivanua carried in the tanoa - to represent the logo and trophy for the annual Ratu Sukuna Bowl interservices rugby competition (see Fig. 4), this provides a potent metaphoric symbol of "Fijian-ness" and authority, reinforced through inferred power associated with Fiji's military and police who compete for the Ratu Sukuna Bowl. More overt 
Fig. 5 Postcard: iTaukei serving yaqona. (Source: Siers, J., c1979, author of Fiji in color)

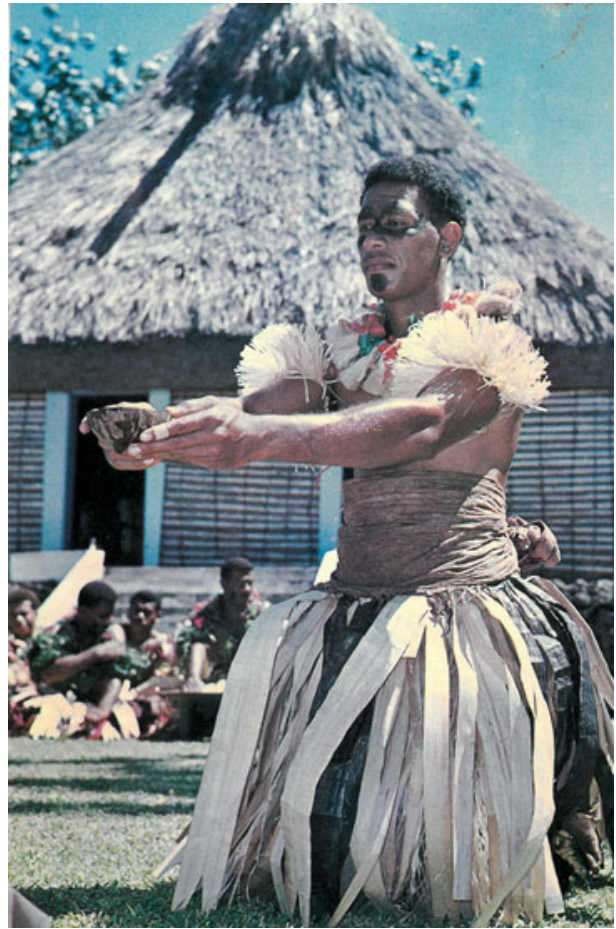

Fig. 6 Postcard: tanoa (yaqona bowl) and images of sale, export, and research. (Source: University of the South Pacific, undated)

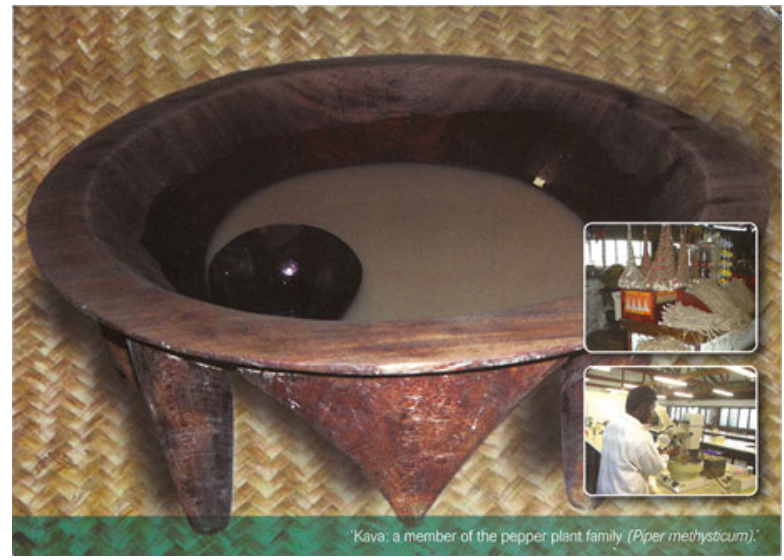

references can be seen within Tourism Fiji advertising and on postcards and prepaid telecards (see Figs. 5, 6, and 7). 
Fig. 7 Telecard: Fijian mixing yaqona. (Source: Fiji Posts and

Telecommunications Limited 1994)

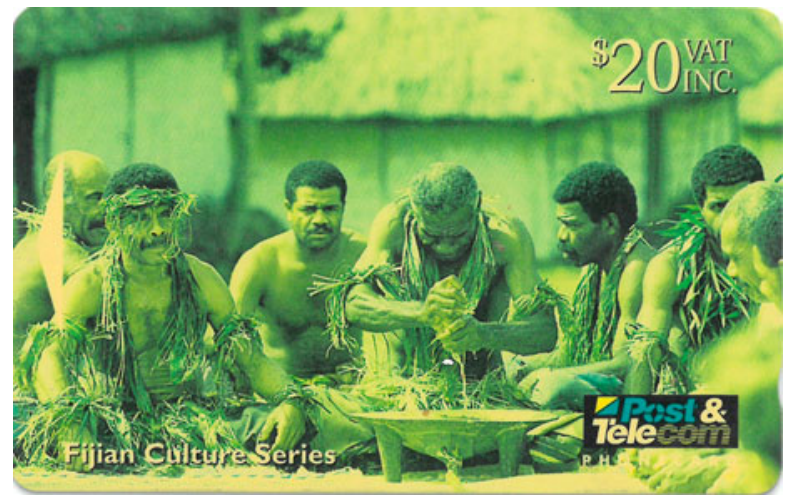

Fig. 8 Official seal of Western Samoa

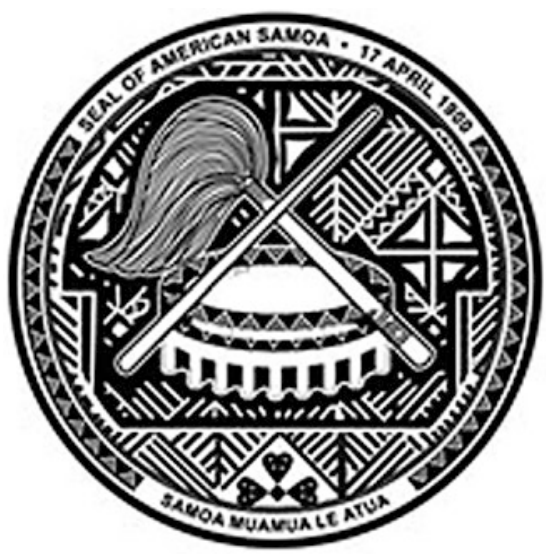

\section{Yaqona (Kava) and Other Symbols of Collectivism}

Symbols and icons are an important part of defining collectivist identities (Linnekin 1990). Hamrin-Dahl (2013) goes further, suggesting that collectivism through Pacific Islanders' use of traditional objects, icons, and practices in the postcolonial period affirms a construct of identity in contrast with the European "other." She states that in contemporary Hawaii and Samoa, the kava bowl has now been adopted as a "national symbol" of postcolonial identity and sovereignty (ibid., 2013, p. 32). In addition to a kava bowl, the official Seal of American Samoa (Fig. 8) includes a fue (fly switch), another object of traditional significance to a number of Oceanic Pacific ethnicities. Other Pacific icons include the taro plant, coconut palm, frangipani flower, and kava. 


\section{Fijian-ness, Yaqona, and Government}

The Fijian Government also acknowledges the importance of yaqona to ethnocultural identity, supported by the Institute of iTaukei Language and Culture $(I T L \& C)$ who are tasked with "preserving iTaukei [indigenous Fijian] identity" (Ministry of Information, 2010, p. 1). In an article discussing the work of the Institute, a large photograph of two Fijian's dressed in traditional costume mixing yaqona is included, clearly linking the practice with the stated objective of preserving cultural identity. Drawing on a number of scholars, former IiTL\&C researcher Sekove Degei (2007) remarked: "To the Fijians, yaqona is a link to the past, a tradition so inextricably woven into the fabric of culture, that life and social processes would be unimaginable without it. Although the use of kava is common among other people groups in the South Pacific, for the Fijian, yaqona is clearly linked to concepts of identity" (p. 3).

\section{What Do Fijians Say About Yaqona}

In 2014, Fijian school teachers were interviewed about their yaqona use and questioned as to whether restrictions on nightly yaqona use were necessary to limit kava hangover aimed at improving teaching ability (Aporosa 2014). A school principal objected strongly to the idea of yaqona prohibition stating: "No one can stop us from drinking yaqona. People might try to stop us but they can't because it is part of our culture" (p. 153). A teacher agreed, arguing that "Yaqona is the cornerstone of our culture" (p. 151). Yet another teacher responded, "People can encourage us to stop [drinking yaqona], but this is about our culture, itovo [custom, manner], the vanua" (p. 159), inferring yaqona's significance to cultural practice and as an ingestible representation of the land, people and culture.

\section{Yaqona and Ethno-cultural Identity in Diaspora}

As Fijians and other Oceanic kava using peoples have migrated, they have taken their yaqona/kava drinking practices with them. That use of yaqona/kava in diaspora acts as a "visible means of affirming and demonstrating their Pasifika-ness," playing a key role in maintaining connectedness to one and the other in both their new and old "homelands" and to assert their ethno-cultural identity (Aporosa 2015, p. 62). Some of that diasporic kava use has also influenced the opening of contemporary kava outlets modeled on café's and alcohol-styled bars to cater for non-Pacific kava users (Wolinski 2018). However, of greater interest is a growing cohort of non-Pacific kava users who are joining Pacific diasporic kava using groups and embracing aspects of Oceanic ethno-cultural kava identity and practice. This has been termed diasporic identity formation in reverse and is interpreted by Pacific peoples as affirming the significance of their "cultural keystone specie" and 
icon of identity which further entrenches ethno-cultural kava-related identity (Aporosa 2015).

\section{Critics of "Yaqona as a Symbol of Cultural Identity"}

Overwhelmingly the literature and ethnographic evidence presented points to yaqona/kava as a significant ethno-cultural identifier in Pacific Oceania and particularly Fiji. Although there is a sector within Fiji who criticizes the overuse of yaqona, asserting that this negatively impacts on productivity (Baba 1996; Kava 2002; Singh 2007; Rawalai 2014; for counterargument, see Kumar and Aporosa 2018), this has not lead to a rejection of this cultural keystone species and its related practices in any significant manner. However, more recently Fiji has seen a small but increasing number argue that yaqona is not part of their identity or ethnocultural expression. Most of these critics tend to belong to evangelical Christian denominations such as the All Nations, New Methodist, and Assemblies of God Churches (Aporosa 2014, pp. 154-157). Countering this message are the older denominations such as the Wesleyan and Catholic Churches who mostly continue to support yaqona use and practice. Ryle (2010) points out: "Pacific theologians have even related the kava ceremony to the Christian Eucharist,... [paralleling this with] themes of self-sacrifice, leadership and service" (p. 20). The Samoan Catholic Church, for instance, identifies "Jesus Christ as a Heavenly Kava Root at Bethlehem" (Taofinu'u 1973, p. 2).

Samoan Wesleyan Methodists believe that kava has a redemptive significance in the same manner as the Blood of Christ (Fa'asi'i 1993, p. 62). In the case of Fiji, Toren (1988, p. 709) also sees a likeness between images of Christ's Last Supper with the yaqona circle. She advances that Leonardo da Vinci's tapestry of The Last Supper "evokes the image of a group of clan chiefs [drinking yaqona] with the paramount chief [Jesus] at their centre." The tapestry image and symbolism, Toren argues, is "a material manifestation of "the Fijian way" (p. 696), thereby epitomizing "Fijian-ness" (see also Ryle 2010, pp. 23-5).

What then has influenced Fijians from the newer Pentecostal Christian denominations to deny the link between yaqona and their identity? This appears to have its roots in the pre-colonial use of yaqona as a conduit for communication between traditional priests and their ancestral gods (Turner 1986; Lebot et al. 1997; Linnekin 1997). New Methodist Church co-founder Reverend Atu Vulaono has declared that yaqona "is a hold-over from pre-Christian religion and not from God" (Titus 2009; also see Vulaono 2001). He has stipulated that yaqona is the "drink of Satan," used to disrupt Fijian lifeways (Fiji Times 2008a, p. 2, b, p. 2). The idea that kava is the "drink of Satan" has become one of Vulaono's signature messages (FBC 2017) and has been adopted by other Pentecostal Churches aimed at eliminating the consumption of yaqona in Fiji (Aporosa 2014).

While some view the criticism of yaqona by Pentecostal Christians as an opportunity for lighthearted joking, what has been more revealing are comments that Vulaono has rejected his culture. In the minds of many, Vulaono has forfeited his 
identity and cultural standing, not because he has ceased yaqona consumption but because he believes yaqona is the drink of and instrument of Satan (Aporosa 2014, p. 153). This connection to the devil is considered a threat to what yaqona symbolizes, an ingestible manifestation of the vапиа and an icon that demonstrates Fijian-ness and therefore Fijian identity.

The Biblical reference often cited by Pentecostal preachers to support their antiyaqona message is "Therefore, if anyone is in Christ, he is a new creation; the old has gone, the new has come!" (NIV 2011: 2 Corinthians 5:17). With many of the practices associated with yaqona having their foundations in the precontact preChristian era, neo-Christian denominations frequently categorize yaqona as belonging to "the old." Additionally the old can also include selected meke (traditional dance) and the use of tabua (whale's teeth) and yaqona as part of marriage negotiation (Ravuvu 1983, p. 46). In contrast, "the new" is deemed to be an abandonment of "the old" traditional ways, with members of these new Pentecostal denominations encouraged to embrace alternative forms of cultural expression such as the giving of boxes of soap instead of tabua and the consumption of orange juice as a replacement for yaqona, in marriage negotiations.

\section{Fundamental Questions as to the Role of Yaqona}

For many, yaqona's link to mana and the vanua prevents it from being substituted with other offerings, items some argue represent "plastic protocols." This is particularly the case in solemn ceremonies such as the ethno-culturally based restorative justice process of matanigasau (Ratuva 2002; Cretton 2005). In these apology ceremonies, parties meet, present, and mix yaqona and discuss the issues that led to conflict or relational breakdown and seek resolution. As yaqona is seen as an ingestible manifestation of the vanua, the apology ceremonies, with its sharing of yaqona, symbolically demonstrates the reuniting of the vanua, a process that many argue would lack efficacy with orange juice - or the Pentecostal substitute that has no connection to the vanua. This not only has the potential for the loss of traditional knowledge and cultural identity but also has the likelihood to disrupt sociocultural harmony.

Twenty-five years ago, the UNESCO reported that "the loss of culture," or cultural identity, is at "the heart of our... social problems" (Teasdale and Teasdale 1992a, p. 1). This they argued was not limited to indigenous cultures but also the "dominant societies of the west, who have moved so far along the road of capitalism, with its emphasis on competition, the consumption of goods and services, and the exploitation of the world's non-renewable resources, that they too are losing their deepest roots" which in turn has seriously impacted sociocultural stability. The UNESCO report concluded that "Culturally appropriate teaching and learning is integral" to sociocultural stability, a process and goal that is reliant upon depth of ethno-cultural identity (Teasdale and Teasdale 1992b, p. 70). Thaman (1992) concurs, arguing that a lack of understanding of one's personal culture is a factor in the breakdown of sociocultural values (see also Rao and Walton 2004). 
Regardless that a strong divide exists between Fijians who argue that yaqona does and does not comprise or reflect their identity, Dalton et al. (2001) initiate valuable commentary which brings clarity to this implied impasse. They draw on Community Psychology's Ecological Levels (also known as systems theory) and state that "Individuals, societies, and the layers of relationships between them are interdependent" (p. 13). Newman and Newman (2011) add:

Systems theories take the position that the whole is more than the sum of its parts... Any system - whether it is a cell, an organ, an individual, a family, or a corporation - is composed of interdependent elements that share some common goals, interrelated functions, boundaries, and an identity. The system cannot be wholly understood by identifying each of its component parts. The process and relationships of those parts make for a larger, coherent entity. The language system for example, is more than the capacity to make vocal utterances, use grammar, and acquire vocabulary. It is the coordination of these elements in a useful way in a context of shared meaning. Similarly, a family system is more than the sum of the characteristics and components of the individual members. (p. 50)

As Newman and Newman (2011) note, system theory includes identity. Therefore the identity of the majority "cannot be ... [altered or subverted, by the personal opinions of] its component parts." It is the majority that dictate the "context of shared meaning" or, in the case of this chapter, ethno-cultural identity. As such, assertions that "yaqona is not part of some Fijians' identity," whether imagined or hoped for, do not alter yaqona's fundamental link with ethno-cultural identity for the majority of Fijians, a union also found throughout other Oceanic Pacific kava using societies in both original and diasporic locations.

\section{Conclusion}

This chapter has examined yaqona/kava as an ingestible representation, manifestation, and embedded symbol of ethno-cultural identity in Oceania and in particular Fiji. This chapter has demonstrated that yaqona/kava not only plays a critical role in Fijian ethno-cultural identity but has also been adopted by selected non-Pacific peoples to enhance their own notions of self. However, this in turn has raised questions as to why some believe this iconic symbol and ritual drink does not comprise their identity in the same way. Reasons argued against yaqona include impacts to productivity and anti-yaqona rhetoric stemming from inside Fiji from the newer neo-Christian fundamentalist Churches with their foundations outside of the country. This tension however is not considered sufficient to limit yaqona/kava in Fiji or Oceania in general, owing to the depth of observance and practice. In summing up, while some may dispute and wish to undermine the significance of yaqona/kava as the dominant symbol of ethno-cultural identity - such as asserting that "yaqona is not part of my identity" - this simply reflects a minority opinion. 


\section{Cross-References}

Cultural Renaissance in a Globalized World

- Diaspora and Changing Ethnic Identities

- Ethnic Identity and Religion

$\checkmark$ Ethno-cultural Identity and Art

- Ethno-cultural Symbolism and Group Identity

- Globalization of Pacific Identities

- Museums and Cultural Identity

Perception, Imagery, and Race

\section{References}

Aporosa S (2008) Yaqona and education in Fiji: a clash of cultures? VDM Verlag, Germany

Aporosa S (2011) Is kava alcohol?: the myths and the facts. J Commun Health Clin Med Pac 17(1):157-164

Aporosa S (2014) Yaqona (kava) and education in Fiji: investigating 'cultural complexities' from a post-development perspective. Massey University, Directorate Pasifika@Massey, Albany

Aporosa S (2015) The new kava user: diasporic identity formation in reverse. N Z Sociol 30(4):58-77

Aporosa S (2017) Understanding cognitive functions related to driving following kava (Piper methysticum) use at traditional consumption volumes. J Psychopharmacol 31(8):A84

Aporosa S, Tomlinson M (2014) Kava hangover and gold-standard science. Anthropologica (J Can Anthropol Soc) 56(1):163-175

Baba P (1996) Yaqona: it is getting the nation doped? Weekend: Fiji Times Mag. 6 April, 2

Balick M, Lee R (2009) The sacred root: Sakau en Pohnpei. In: Balick M (ed) Ethnobotany of Pohnpei: plants, people, and island culture. University of Hawai'i Press in association with The New York Botanical Garden, Honolulu, pp 165-203

Crawford AL (1981) Aida: life and ceremony of the Gogodala. National Cultural Council \& Robert Brown \& Associates, Bathurst

Cretton V (2005) Traditional Fijian apology as a political strategy. Oceania 75(4):403-417

Dalton J, Elias MJ, Wandersman A (2001) Community psychology: linking individuals and communities. Wadsworth, Belmont

Dean E, Ritova S (1988) Rabuka: no other way. Doubleday, Sydney

Degei S (2007) The challenge to Fijian Methodism: the vanua, identity, ethnicity and change, (unpublished Master's thesis), Anthropology Program, The University of Waikato

Fa'asi'i U (1993) Gospel and culture in the ava ceremony. J Theol sIIn10:61-63

FBC: Fiji Broadcasting Commission (2017) Cucurui (S01E01): Yaqona - Pastor Atunaisa Vulaono. April 2. Retrieved from https://www.youtube.com/watch?v=WY8XE4W7doo

Fehoko E (2014) Pukepuka fonua: an exploratory study on the faikava as an identity marker for New Zealand-born Tongan males in Auckland, New Zealand. (unpublished Master's thesis), Auckland University of Technology

Fiji Times (2008a) Kava is evil, says minister, Fiji Times 24 August, 2

Fiji Times (2008b) New Methodist warns on kava, Fiji Times 22 August, 2

Finau S, Stanhope J, Prior I (2002) Kava, alcohol and tobacco consumption among Tongans with urbanization. Pac Health Dialog 2:59-68

Garibaldi A, Turner N (2004) Cultural keystone species: implications for ecological conservation and restoration. Ecol Soc 9(3):1-19

Geraghty P (1996) "When I was a lad. ..": thoughts on our national drink. Fiji Post: 16. April 28

Hamrin-Dahl T (2013) The kava bowl wonders: can the fetish be named? Etnografiska, Germany 
Huffman K (2012) Kava: a Pacific Elixir. MUSE (J Sydney Univ Mus) 1:24-25

Kava R (2002) The adverse effects of kava. Pac Health Dialog 2:293-296

Kirch PV, Green RC (2001) Hawaiki: ancestral Polynesia. Cambridge University Press, Cambridge, UK

Kumar A, Aporosa S (2018) Anti-kava campaign: give up for a month and feel the difference. Radio Tarana (via Stuff.co.nz), Sept. 14. Retrieved from https://www.stuff.co.nz/tarana/107029166/ antikava-campaign-give-up-for-a-month-and-feel-the-difference

Lal B (1985) Review of Fiji: the three-legged stool. Selected writings of Ratu Sir Lala Sukuna. Aust Hist Stud 21(84):433-466

Lebot V, Cabalion P (1988) Kavas of Vanuatu: cultivars of Piper methysticum frost (vol. technical paper no.195). South Pacific Commission, Noumea

Lebot V, Merlin M, Lindstrom L (1992) Kava: the Pacific drug. Psychoactive Plants of the World Series. Yale University Press, New Haven

Lebot V, Merlin M, Lindstrom L (1997) Kava, the Pacific elixir: The definitive guide to its ethnobotany, history and chemistry. Vermont, Healing Arts Press

Lim TK (2016) Edible medicinal and non-medicinal plants: volume 11, modified stems, roots, bulbs. Springer, New York

Lindstrom L (2004) History, folklore, traditional and current uses of kava. In: Singh YN (ed) Kava: from ethnology to pharmacology (medicinal and aromatic plants - industrial profiles volume 37). CRC Press, Boca Raton, pp 10-28

Linnekin J (1990) The politics of culture in the Pacific. In: Linnekin J, Poyer L (eds) Cultural identity and ethnicity in the Pacific. University of Hawaii Press, Honolulu, pp 149-174

Linnekin J (1997) The ideological world remade. In: Denoon D, Meleisea M, Firth R, Linnekin J, Nero K (eds) The Cambridge history of the Pacific islanders. Cambridge University Press, Cambridge, UK, pp 397-438

Matthias J (2014) AUT study: kava keeps young Tongans out of trouble, The New Zealand Herald. Online at: http://www.nzherald.co.nz/education/news/article.cfm?c id=35\&objectid= 11367162

Minahan JB (2012) Ethnic groups of South Asia and the Pacific: an encyclopedia. ABC-CLIO, California

Ministry of Information, National Archives and Library Services (2010) Going back to our roots: IILC to preserve iTaukei identity. New Dawn: Gov Fiji 2(5):1

Newman B, Newman P (2011) Development through life: a psychosocial approach (11th ed). Wadsworth/Cengage Learning, California

NIV - New International Version (2011) The Bible: 2 Corinthians. Online at: http://www.biblica. com/en-us/bible/online-bible/?translation $=$ niv\&book $=2+$ corinthians\&chapter $=5$

Payson R (2008) The culture of kava: a visual journey of rituals and ceremonies among rural Fijians. (unpublished Master's of Social Science thesis). Brooks Institute of Photography

Pollock N (1995) Introduction: the power of kava. In: Pollock N (ed) The power of kava, vol 18. Australian National University, Canberra, pp 1-19

Rao V, Walton M (2004) Culture and public action: relationality, equality of agency, and development. In: Rao V, Walton M (eds) Culture and public action. Stanford Social Sciences, Stanford, pp 3-36

Ratuva S (2002) Re-inventing the cultural wheel: re-conceptualizing restorative justice and peace building in ethnically divided Fiji. In: Dinnen S, Jowett A, Newton T (eds) A kind of mending: restorative justice in the Pacific Islands. Pandanus, Canberra, pp 149-163

Ratuva S (2007) Na kilaka a vaka-Viti ni veikabula: indigenous knowledge and the Fijian cosmos: implications for bio-prospecting. In: Mead A, Ratuva S (eds) Pacific genes and life patents: pacific indigenous experiences and analysis of the commodification and ownership of life. Call of the Earth Llamado de la Tierra and the United Nations University of Advanced Studies, Wellington, pp 90-101

Ravuvu A (1983) Vaka i Taukei: the Fijian way of life. University of the South Pacific, Suva 
Rawalai L (2014) 'Kavaholics' told to drink in moderation. Fiji Times. Online at: http://www. fijitimes.com/story.aspx?id=278962. Accessed 1 Sept 2014

Ryle J (2010) My god, my land: interwoven paths of Christianity and tradition in Fiji. Ashgate, Surrey

Scarr D (1980) Ratu Sukuna: soldier, statesman, man of two worlds. Macmillan Education, London

Singh M (2007) The good and bad of kava, Fiji Sunday Times, 2 September, 7

Taofinu'u P (1973) O le 'ava o se peloferaga: the kava ceremony as a prophecy. Roman Catholic Church, Apia

Teasdale J, Teasdale B (1992a) Introduction. In: Teasdale K, Teasdale B (eds) Voices in a seashell: education, culture and identity. Institute of Pacific Studies, University of the South Pacific and United Nations Educational, Scientific and Cultural Organisation, Suva, pp 1-5

Teasdale J, Teasdale B (1992b) Culture and the context of schooling. In: Teasdale K, Teasdale B (eds) Voices in a seashell: education, culture and identity. Institute of Pacific Studies, University of the South Pacific and United Nations Educational, Scientific and Cultural Organisation, Suva, pp 54-70

Tengan TPK (2008) Native men remade: gender and nation in contemporary Hawai'i. Duke University Press, North Carolina

Thaman K (1992) Cultural learning and development through cultural literacy. In: Teasdale K, Teasdale B (eds) Voices in a seashell: education, culture and identity. Institute of Pacific Studies, University of the South Pacific and United Nations Educational, Scientific and Cultural Organisation, Suva, pp 24-36

Titus P (2009) Fijian Methodist Church challenges military government, Touchstone: monthly newspaper of The Methodist Church of New Zealand. August, 1,8

Tomlinson M (2004) Perpetual lament: kava-drinking, Christianity and sensations of historical decline in Fiji. J R Anthropol Inst 10:653-673

Toren C (1988) Making the present, revealing the past: the mutability and continuity of tradition as process. Man 23(4):696-717

Turner J (1986) The water of life: kava ritual and the logic of sacrifice. Ethnology 25(3):203-214

Vakabua J (2007) A Fijian's perspective on the uses and ownership of intellectual property. In: Mead A, Ratuva S (eds) Pacific genes and life patents: pacific indigenous experiences and analysis of the commodification and ownership of life. Call of the Earth Llamado de la Tierra and the United Nations University of Advanced Studies, Wellington, pp 102-109

Vulaono A (2001) Revelation on kava/snake, Online at http://www.visionprovider.net/prophecies/ yaqona-prophecy.html. Accessed 20 Aug 2010

Wolinski C (2018) This ancient South Pacific sipper is officially trending. VinePair (online), March 21. Retrieved from https://vinepair.com/articles/what-kava-kava-drink/

Young M (1995) Kava and Christianity in Central Vanuatu (with an appendix on the ethnography of kava drinking in Nikaura, Epi). In: Pollock N (ed) The power of kava, vol 18. Australian National University, Canberra, pp 61-96

Zagefka H (2016) Ethnicity, concepts of. In: Smith AD, Hou X, Stone J, Dennis R, Rizova P (eds) The Wiley Blackwell encyclopaedia of race, ethnicity, and nationalism. Wiley, West Sussex, pp 761-763 